\title{
Apprenticeship orientation as planned behavior in educational choices: a path model of antecedent beliefs
}

\author{
Kalervo Friberg
}

\author{
Correspondence: kalervo.friberg@ \\ helsinki.fi \\ Institute of Behavioural Sciences, \\ University of Helsinki, 00014 \\ Helsinki, Finland
}

\begin{abstract}
Background: A hypothetical descriptive behavioral model extending the theory of planned behavior (TPB) was examined for subjective perceived control beliefs as antecedents of the apprenticeship orientation for vocational-educational training (VET). Attributes of self-regulation and self-regulatory systems in belief formation, and affective evaluation, were expected to vary with student choice of apprenticeship in an educational path.
\end{abstract}

Methods: A research question concerning initiative, independence, and self-guidance, hypothesized to be proximal antecedents of part-time job willingness and apprenticeship willingness was answered. A survey of ninth-grade students in Finnish comprehensive school was conducted after implementation of a work-orientation program. At the local school system level, 649 subjects of the mean ages of 16.0 years participated in a web-based survey in two school districts in the south-west of Finland in 2010. The observed variables were inserted for Path Analysis conducted in IBM Analysis of Moment Structures. Factor Analysis was used as a preliminary step for Path Analysis.

Results: The variables formed a fitting belief-based path model for the interaction of initiative, independence, and self-guidance in apprenticeship conation. Part-time Job willingness served as a mediating variable. Independence interest belief and the mediating variable part-time willingness correlated negatively. Initiative showing interest and self-guidance want contributed positively to apprenticeship conation.

Conclusions: The findings gave tentative evidence of subjective antecedent beliefs linking Self-Direction and Apprenticeship willingness.

Keywords: Planned behavior; Apprenticeship; Initiative; Self-guidance; Antecedent beliefs

\section{Springer}

\section{Background}

Ajzen and Fishbein (1977), p888 have argued that a person's attitude toward an object influences the overall pattern of his or her responses to the object and a person's intention is in turn a function of his or her attitude toward performing the behavior in question. The attitude construct in this paper followed the Fishbein and Ajzen expectancy model (1975) where we obtained a belief-based measure of attitude (Ajzen 1991, p191). Attitude in this case was defined as the overall attitude toward apprenticeship as a choice of further training and continued education, and the beliefs were subjective 
probabilities of the relations of initiative, independence, and self-guidance to part-time job willingness and apprenticeship.

With the aim of improving the predictive power of attitude-integrated models of behavior, including additional determinants of behavior such as social norms or intentions, several theories have been developed (Olson and Zanna 1993). Ajzen (1985, $1987,1988,1991)$ presented a theoretical model - the theory of planned behavior (TPB) -as an extension of the theory of reasoned action (TRA) (see Ajzen and Fishbein 1980; Fishbein and Ajzen 1975) extending the TRA to include measures of a control belief and a perceived behavioral control (PBC) (see Armitage and Conner 2001). For a graphical presentation of the TPB, see Figure 1.

Ajzen (2005), p136 writes that the TPB has important implications for interventions designed to change intentions and behavior although the theory has been used primarily to explain and predict behavior in various domains. In this study, I assumed that perceived behavioral control (PBC) would emerge in the form of a linear path model of a person's orientation to apprenticeship, and the path would present antecedents of apprenticeship choice. It was hoped that the emerging model would further identification of the determinants of behavioral intentions and understanding of human behavior (see Ajzen 2005), and could contribute to planning and implementing educationalvocational interventions. Fishbein has commented that one good indicator of the usefulness of models such as the TPB is their power to help design effective interventions that produce behavior change (see Conner and Armitage 1998, p1453).

The attributes of the PBC in the hypothesized model were derived from a factored test (see the section "Test design"). Research with factored tests can lead to greater understanding of the determinants of educational success and failure (Kline 2000, p367). Factor analysis mirrors the cognitive processes whereby human beings actually make judgments about differences in objects (Rust and Golombok 1999, p100). Rust and Golombok have presented extensive research on the psychometric requirements of factor analysis (1999). The survey questionnaire used in this research had been prepared to meet the requirements of personality questionnaires of factorial model (for extensive evaluation of questionnaires of this model, see Kline 2000, pp489-538). The method in extraction was Maximum Likelihood with Direct Oblimin rotation. Factor loadings less than 0.3 were suppressed in order to aid the interpretation. The data reduction revealed a factor domain, which is descriptively labeled as Self-Direction. This variable included varying latent attributes of self-regulation, self-efficacy, and selfdetermination as the constructs Initiative, Independence, and Self-guidance.

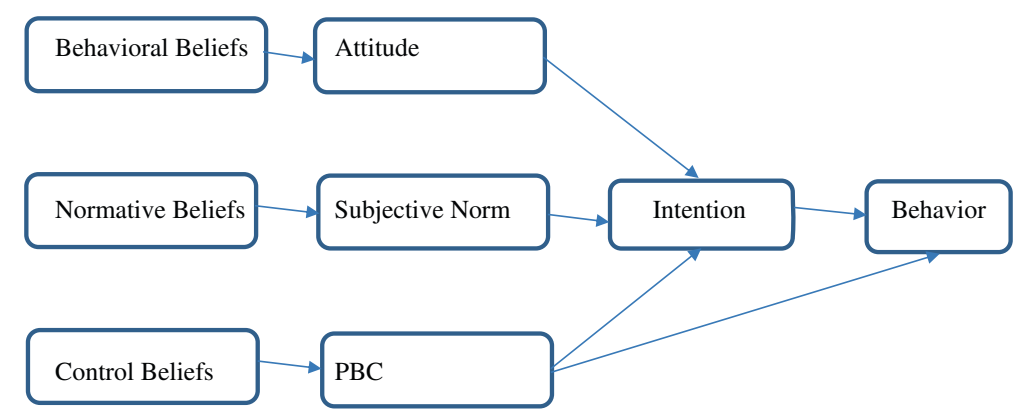

Figure 1 The theory of planned behavior. 
Self-regulation can be considered to be an aspect of conation (see Bandura 1997; Miller 1991). Self-regulation refers to self-generated thoughts, feelings, and actions that are planned and cyclically adapted to the attainment of personal goals (Zimmerman 2000, p14). Self-regulation involves self-efficacy or perceived self-efficacy (see Ajzen 2002, p667; Bandura 1977, 1989, 1997). Self-efficacy, in turn, consists of beliefs about one's capabilities to organize and implement the actions necessary to attain the designated performance of a skill for specific tasks (Zimmerman 2000, p14).

In organismic theories of motivation, organisms are viewed as active, volitional and capable of initiating behaviors (Deci and Ryan 1985, p4). In this paper, students are seen as active, self-determined individuals who make decisions in a planned way. These individuals are guided by belief systems including that of control of perceptions. Individual conative issues such as intentions and goals, plans and commitments meet the demands and expectations of educational policy. In actualization of cognitive and affective skills, intrinsic and extrinsic motivation could be theorized to complement each other. Deci and Ryan (1985) p35 show that self-determination is important in the development and exercise of extrinsic and intrinsic motivation. Intrinsically motivated people perceive the locus of causality to be internal (Deci and Ryan, 1985 p34). In order to understand an individual's choice patterns, it is also relevant to take into account the conception of student motivation emphasizing the interaction of individual and contextual factors (Tapola and Niemivirta 2008, p291).

Apprenticeship as part of vocational education and training has recently become a target of national and global interest (see Kersh and Evans 2010). Thus, gaining and entering an apprenticeship is one of the choices for students in the education-work transitions in Europe (European Commission 2012) when considering initial entry to work. In the United States, apprenticeships increased by 25\% between 1997 and 2003 (Lerman 2010).

\section{Governance and structure overshadows perceived behavioral control}

It can be argued that educational research emphasizing empirical student-centered findings including primary level students' beliefs, motivations and choice models for future career and educational choices, is less present in educational policy discussions and in educational interventions than governance- and structural-centered approaches. Internationally, apprenticeships and vocational education and training have been approached extensively from a descriptive point of view and supplemented by international comparative analyses (Rauner and Smith 2010, p1). In educational research, apprenticeships have been approached from a variety of perspectives (see Ainley and Rainbird 1999), and different theories in this regard have been formulated. These include developmental and social learning theory approaches to career counseling that focus on the process of career choice (Hackett 2002). Structural factors including job and training opportunities have long been shown to affect career behavior (Hackett 2002; Mitchell and Krumboltz 1990).

\section{Importance of personal dimensions}

Career awareness is fundamental to career exploration, preparation and choice (Turner and Lapan 2013, p539; for effectiveness of evaluation of career counselling, see chapter 
four, Kidd 2006). Extensive research has been done linking different theoretical personenvironment fit models with person-environment psychology. Major theories in career choice include the Minnesota Theory of Work Adjustment (see Swanson and Schneider 2013) and Holland's Theory of Vocational Choice and Adjustment (see Nauta 2013). The Life Span, Life Space Theory of Careers, and Social Cognitive Career Theory are also significant (see Hartung 2013; Lent 2013).

Students undergoing their initial education and training face important educationwork transitional periods that include societal and personal dimensions. The national educational policy guiding work-life orientation in Finland (National Board of Education 2004) lists two main purposes for school-based work-life orientation, which are expected to have an impact on students' developmental processes. The first is to bring schools and the surrounding society closer, and the second is to facilitate students' choices for future career and education. It is hoped that this paper will contribute to the knowledge of latent antecedent individual behavior models that again make it possible to design effective intervention models. As Fishbein and Ajzen (1975) have remarked, "If we want to change attitudes first we have to attack beliefs."

Societal transitional patterns include characteristics of labor markets (Marsden 1986), regulated and deregulated modes of inclusion and exclusion (Garonna and Ryan 1991), and qualification of space and organizational space (Maurice et al. 1986). Characteristics of education systems such as stratification and standardization (Allmendinger 1989), linkages with the labor market (Hannan et al. 1996), and the occupational specificity of vocational education (Müller and Shavit 1998) are also important. Research in expected vocational effects and in expected impacts has yielded contrasting predictions (Iannelli and Raffe 2007) in different theoretical frameworks including human capital theories (Becker, 1975), signaling and job queue (Spence 1974; Thurow 1975; Wolf 2002), and network theories (Rosenbaum, et al. 1990).

In work-based learning, learners' motivation is considered a relevant contributor to the learning process (Kersh and Evans 2010). In career development and counseling individual perceptions of abilities (Lent et al. 1994) have been highlighted and standardized ability self-estimate measures have been developed (see Campbell et al. 1992; Harrington and Harrington 1996; Holland et al. 1994). Learners' personalities, backgrounds, and environments are significant factors related to learning environments at a workplace (Kersh and Evans 2010). In the developmental approach (see e.g., Super 1974, 1980) and during the early stage of career development, the focus is on educational and occupational decision-making (Kidd 2006).

Reliable and valid data are needed about both individuals and jobs (Kidd 2006). Beliefs are relatively stable individual differences, but they also are highly dynamic (Dweck 2000, p133). Beliefs and attitudes coexist. People are engaged in processes when they pursue self-relevant goals in their daily lives (Dweck 2000; see also, Breckler and Greenwald 1986; Deci and Ryan 1991; Epstein 1990). In order to be able to influence and change belief systems and behavior patterns, data is needed from their structures and models.

\section{Research question and hypotheses}

The TPB was originally designed to predict and explain human behavior in specific contexts. In this research paper, a stratified adaptation of the TPB was used in the 
context of apprenticeship conation. The adapted model presented relations among beliefs, attitudes, and intentions for the purpose of modeling and explaining the variance of attitude and apprenticeship choice in a lateral process. Attitude (personal evaluation of behavior) had been a theoretically relevant and important concept in the theory of planned behavior (Ajzen 1991, p199).

For the theoretical model of this study, see Figure 2.

Earlier studies had linked Self-Direction (see Guglielmino and Guglielmino 1988; Brockett and Hiemstra 1991) to learning. Learning forms a path into changing intentions and behavior. The three variables of Self-Direction in this research project were chosen to measure the hypothesized attitude domains of self-determination, selfregulation, and intrinsic and extrinsic motivation in relation to apprenticeship as a choice for a future education path. The hypothetical model in this study was a modification of the TPB model (see Conner and Armitage, 1998). In this model, the PBC element of the TPB comprised subjective perceived initiative, independence, and selfguidance. The mediating variable Part-time Job was hypothesized to be a facilitating factor indirectly revealing intention (intention element in the TPB) in a behavioral act (conation) in choosing apprenticeship training (a behavioral element in the TPB).

The main research question was:

Does Self-Direction converge to Apprenticeship?

The two hypotheses to be tested in this study were:

1. Subjective beliefs of initiative, independence, and self-guidance as perceived behavioral control vary significantly with intermediating variable Part-time Job and target variable Apprenticeship

2. A linear behavioral model exists as a function of Self-Direction, intermediating the intention element and choice of apprenticeship

As mentioned earlier in this paper, entering an apprenticeship is affected by not only national school policy, guidance, and opportunity, but also by work-related attitudes, habits, and interpersonal skills; they all serve as important predictors of job success and satisfaction. Individuals' belief systems and motivational systems influence the goals they choose to pursue and how intrinsic versus extrinsic their motivation tends to be (Dweck 2000). The individual student choice models for person-environment fit and

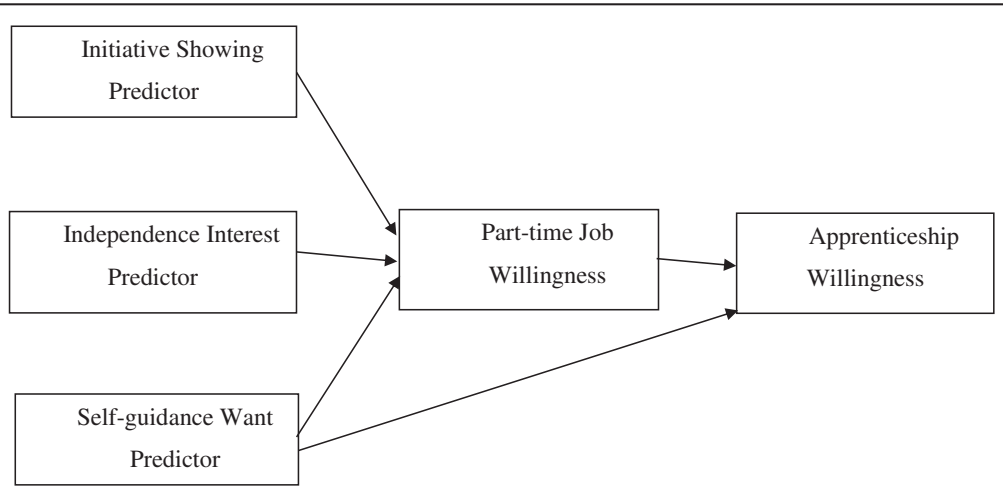

Figure 2 Conceptual path model being tested (based on Ajzen 1991). 
decision-making (see Holland 1997; Super 1957, 1974, 1980) are the focus of this research paper.

\section{Method}

\section{Test design}

The design was used to measure hypothesized respondents' beliefs as representations of variations in attitudes (see Rust and Golombok 1999). There was a functionality approach in the test construction that was the breakdown of a curriculum-based educational-vocational intervention program into relevant, valid local criterion-based variables (Rust and Golombok 1999, p27). The synthesis of function (national school system with local curriculum adaptation) and beliefs (education and work-life related individual attitude variables) designs added to the rationale for creating the measurement instrument used in this research. The test design built on the theory of true scores (see Rust \& Golombok 1999). The measurement instrument was constructed to serve face validity and increase the answer motivation of the participating students (Kline 2000, p18).

\section{Participants}

The samples for this study were drawn from the municipal school districts of Halikko, Salo, and Turku. For standardization of the test, the sampling was based on stratified sampling and special group norms (see Kline 2000, pp52-58). The questionnaire used in this study was developed comparing groups of respondents and their performance as groups so establishing norms was not considered to be crucial (see Rust and Golombok 1999, p217). The stratifying variables used in sampling were state financing, mixed gender, city (town) schools, and the comprehensive school state system.

The observation was conducted during the spring term of the school year 2009-2010. The consolidated municipal school district of Salo (Salo, Halikko, and Perniö) had an enrollment of 577 students, and 525 responses were received (90\%). The city of Turku had an enrollment of 1,337 and 124 responses were received (9\%). The sample consisted of 649 students ( 341 girls and 308 boys of the mean age of 16.0 years).

\section{Materials and procedure}

For the survey, bipolar statements were prepared in the format of Likert's Summated Rating Technique. For a discussion of the methodological issues concerning belief, salience, and optimal scaling in the TPB, see Ajzen (1991, pp191-193) and for issues concerning the principle of compatibility, see (Sutton 1998). The questionnaire was a person-based questionnaire of attitude (Rust and Golombok 1999, p196). It was created for attitude measurement (see Oppenheim 1992). The questions were presented in the native language of the students (Finnish) and were translated into English for this article by the author. Agreement was used as the answering format in a five-step bipolar dimension. Gable (1986), p 5 after reviewing research on the number of question steps, has come to the conclusion that "on the basis of research reported, the reliability and validity issues seem to be best served through the use of from five to seven response categories." Attention was paid to practical and empirical considerations (see Gable 1986, pp41-45; Cronbach 1946, p476), and establishing face validity (Kline 2000, p18) 
through increasing the motivation of the respondents with items relevant to the workorientation program objectives and goals and fitting in the life-space and life-span of the students. Content validity (Kline 2000, p24) was targeted by choosing response items promoting self-awareness and avoiding response sets generating socially desirable answers. All categories of the response continuum were labeled, and horizontal verbal labels were chosen considering the ages of the respondents, and the number of formal school years (nine or more school years). Construct validity of the test was established through a factor analytic approach setting up the test derived from the nature of the variables (Kline 2000, p29). A confirmatory factor analysis step in Path Analysis, testing the meaningfulness of the observed variable loaded the attributes initiative, independence, and self-guidance satisfactorily on the factor Self-Direction. The respective factor loadings were $.64, .75$, and .55 .

The items of the test used in this paper were self-developed by the researcher. The psychometric test design followed a general application viewpoint where the test was determined by its use, in this case testing individual beliefs of a stratified sample in a specific time and in local specified context. The rationale behind using a self-developed measurement instrument was to provide an instrument to assess time, target, space, and location specific control perceptions (for established scales, see Brown and Lent 2013).

The first step in developing the questionnaire was to determine the content area and manifestation specifications that provided the blueprint (see Rust and Golombok 1999, p196). This phase of the survey included item reviews administered by interviewing two directors of education (school superintendents), two comprehensive school principals, and four guidance counselors from the participating school systems and schools. The author conducted the interviews in the fall of 2007.

A pilot study was conducted in the Halikko school district $(n=129)$ in the fall of 2007. An item-analysis was made after piloting. After the analysis, the item wordings and overall layout of the Internet survey were changed to improve the simplicity, clarity, and reliability of the scale design. The response style of this person-based ratingscale questionnaire was changed. The pilot questionnaire had had a five-statement format: I strongly agree, I agree, I cannot tell, I disagree, and I strongly disagree. This was changed to a bipolar format. Although a 7-point scale could have been optimal, a bipolar 5-point Likert type scaling was considered to be acceptable for this paper (see Ajzen 1991, pp192-193). The scale and selection of participants was determined to satisfy the general requirements of continuous scale of measurement and independence of observations in SEM methodology (Babakus et al. 1987; Clason and Dormody 1994; Malone and Lubansky 2012). After revisions to the piloted questionnaire, a Spearman-Brown split-half reliability test (odd-even) was administered in IBM SPSS. The SpearmanBrown Coefficient was 0.7, which was satisfactory for a person-based questionnaire (Rust and Golombok 1999, p214).

An Internet survey was completed under teacher supervision at school in order to improve response reliability. Table 1 shows the attitude attribute items and the bipolar variable structure used in the survey. The observed psychometric properties are presented in Table 2. The psychometric reliability of the test used in this study was that of internal consistency reliability. The minimum of .7 of a good test (Kline 2000, p15) was reached. The reliability, Cronbach's Alpha (internal consistency) of the scale was .7 
Table 1 Survey items for Initiative (exogenous), Independence (exogenous), Selfguidance (exogenous), Part-time Job (endogenous intermediating), and Apprenticeship (endogenous ultimate)

\begin{tabular}{lll}
\hline Variable & Minimum $\mathbf{1}$ & Maximum $\mathbf{5}$ \\
\hline $\mathbf{1}$ Initiative & I am interested in an occupation where I work & I am interested in an occupation where I \\
& following familiar methods and routines. & can show initiative. \\
$\mathbf{2}$ & I am interested in an occupation where I am & I am interested in an occupation where I \\
Independence & supervised. & work independently. \\
$\mathbf{3}$ Self- & I want a job that has detailed instructions. & I want to work in my future occupation \\
guidance & & without specific instructions. \\
$\begin{array}{ll}\mathbf{4} \text { Part-time } \\
\text { Job }\end{array}$ & I would like my workdays or weeks to be full-time. & I am willing to work part-time. \\
$\mathbf{5}$ & I want to be trained at and graduate from school & I am willing to be trained at and \\
Apprenticeship & for my profession. & graduate through apprenticeship. \\
\hline
\end{tabular}

Note. Scale interval in all attributes is integral 1. Items 1-3 measure Self-Direction. The polarities and their respective item coding for variables $1,2,3$, and 4 are reversed from the original survey order.

for the items in Self-Direction, which can be defended to be satisfactory in behavioral attitude measuring for this psychometric evaluation purpose and usage in path analysis. The Spearman-Brown split-half reliability coefficient was .70.

Table 1 Survey items for Initiative (exogenous), Independence (exogenous), Selfguidance (exogenous), Part-time Job (endogenous intermediating), and Apprenticeship (endogenous ultimate)

\section{Results}

The survey data were subjected to statistical analyses in IBM SPSS. Variable skew and kurtosis did not violate the univariate normality assumption for Path Analysis (Hancock and Liu 2012, pp 296-298). Multivariate data missing at random (MAR) were made ready for Path Analysis by multiple imputation (MI) (for MI procedure see Schafer and Olsen 1998). The five variables of the hypothesized model plus were imputed in IBM SPSS. The imputed variables were analyzed for preliminary technical properties (Malone and Lubansky 2012). For the imputed data, see Table 2. All the variance inflation factors (VIFs in SPSS collinearity diagnostics) were between 1.21 and $1.47(<5)$, the eigenvalues were not near zero, and none of the condition indexes were greater than 10; thus, multicollinearity did not exist.

The distributions of the measured variables (univariate) did not show severe problems of distributional assumptions (skewness $>2$; kurtosis $>7$ ) as customarily defined (see West et al. 1995). The correlation matrix of the variables was examined to determine whether weak inter-item dependency existed, or too high correlations would indicate multicollinearity. Neither of these existed. Path Analysis could be used for modeling the variables (see Garson 2012a; Hoyle 2012; Loehlin 2009; Westland 2012).

The sample size of 646 was deemed adequate for Path Analysis (see Hoyle 1995). Initiative, Independence, and Self-guidance were the observed exogenous variables, and Part-time Job and Apprenticeship formed the endogenous variables; the latter of the two endogenous variables was the ultimate (end-node) variable (see Garson 2012a).

\section{Method of analysis}

Initiative Showing, Independence Interest, Self-guidance Want, Part-time Job Willingness and Apprenticeship Willingness were entered in Path Analysis in Analysis of 
Table 2 Psychometric properties of the multiple imputed data in the path analysis

\begin{tabular}{lllllllllllll}
\hline \multicolumn{1}{l}{ Observation properties } & \multicolumn{1}{c}{ Pearson correlations } \\
Variable & $\boldsymbol{N}$ & $\boldsymbol{M}$ & $\mathbf{S D}$ & Variance & Skew & Kurtosis & $\mathbf{1}$ & $\mathbf{2}$ & $\mathbf{3}$ & $\mathbf{4}$ & $\mathbf{5}$ \\
\hline 1 Initiative & 1286 & 3.42 & 0.95 & 0.90 & -0.04 & -0.44 & 1 & $.502^{* *}$ & $.298^{* *}$ & .005 & $.074^{* *}$ \\
2 Independence & 1285 & 3.63 & 0.83 & 0.69 & -0.06 & -0.26 & $.502^{* *}$ & 1 & $.390^{* *}$ & $-.085^{* *}$ & .032 \\
3 Self-guidance & 1287 & 3.28 & 0.88 & 0.78 & -0.05 & 0.13 & $.298^{* *}$ & $.390^{* *}$ & 1 & $.065^{* *}$ & $.151^{* *}$ \\
4 Part-time Job & 1286 & 2.29 & 0.99 & 0.99 & 0.30 & -0.37 & -.005 & $-.085^{* *}$ & $.065^{* *}$ & 1 & $.186^{* *}$ \\
5 Apprenticeship & 1264 & 2.58 & 1.15 & 1.33 & 0.19 & -0.69 & $.074^{* *}$ & .032 & $.151^{* *}$ & $.186^{* *}$ & 1 \\
\hline
\end{tabular}

Note. Range of answers was in all cases $1.0-5.0 .{ }^{* *}$ Correlation is significant at the 0.01 level (2-tailed).

Moment Structures (IBM SPPS Amos). The estimation method was Maximum Likelihood (ML) to ensure consistent, efficient, and unbiased parameter estimates and accurate standard errors (Bovaird and Koziol 2012, p496).

\section{Adapted TPB Path model}

Using the estimation method, a fitting model emerged. Fit indices reported based on Garson's (2012b) recommendations: $\mathrm{X}^{2}(d f=2, \mathrm{~N}=1250)=2.51, p=.284$, RMSEA $=.014$, TLI $=.994$ and CMIN/DF $=1.27$. TLI was used as the baseline measure because of its relation to the average size of correlations among measured variables (Garson 2012b b) and its relative independence of sample size (Marsh et al., 1988, 1996). CMIN/DF was reported as a normed value, which attempts to make model chi-square less dependent on sample size. It penalizes for lack of parsimony and over parameterization (see Garson 2012b b, p42). The RMSEA cut-off for Path Model was good (less than or equal to .08) (Schumacker and Lomax 2004, p82). The lower confidence interval of the RMSEA was .000 and the upper limit .059, thus indicating a wellfitting model (see Figure 3 and Tables 3 and 4).

\section{Discussion}

Results from this study indicated that students' subjective beliefs about initiative, independence and self-guidance as perceived behavioral control varied with intermediating intention part-time willingness and choice target apprenticeship. The data supported

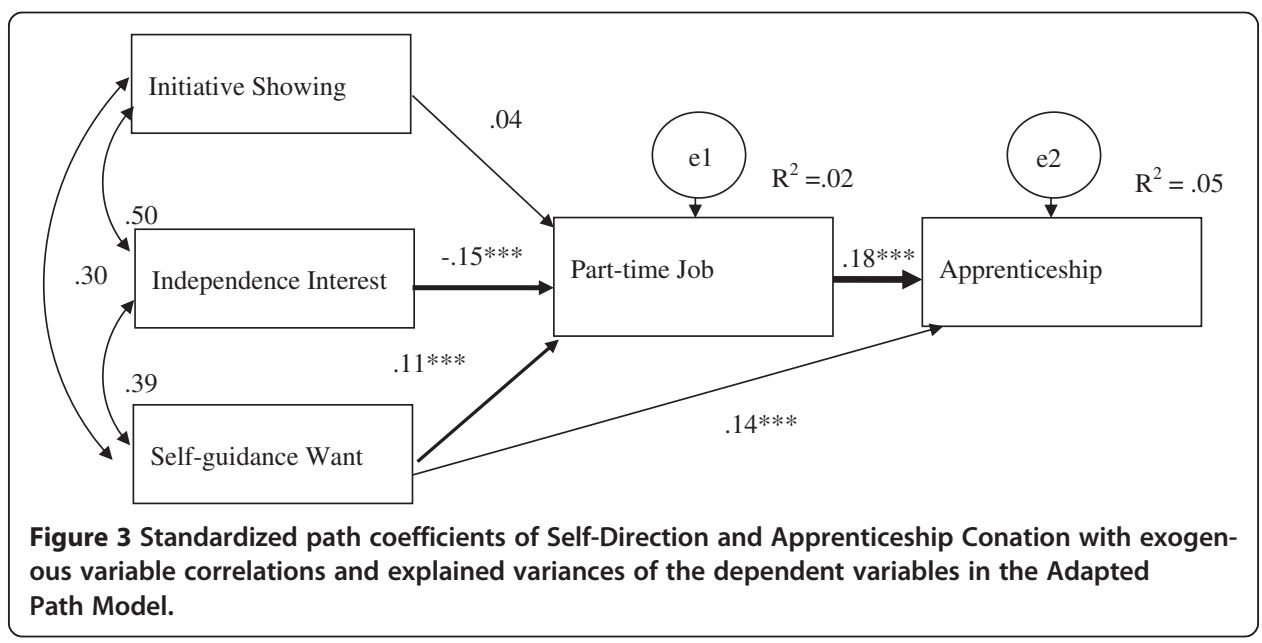


Table 3 Unstandardized Path Coefficients for the Adapted TPB Path Model

\begin{tabular}{lllll}
\hline Model & Estimate & SE & CR & $\boldsymbol{p}$ \\
\hline Parameter & .04 & .03 & 1.19 & .236 \\
1 Initiative showing & -.18 & .04 & -4.45 & $<.001$ \\
2 Independence interest & .13 & .03 & 3.70 & $<.001$ \\
3 Self-guidance & .18 & .04 & 5.06 & $<.001$ \\
4 Part-time Job & .21 & .03 & 6.45 & $<.001$ \\
5 Apprenticeship & & &
\end{tabular}

Note. Estimate = unstandardized path coefficient; $S E=$ standard error of the coefficient; $C R=$ critical ratio; $p=$ probability value.

the assumed linear behavioral model linking Self-Direction, Part-time Job Willingness and Apprenticeship Choice. Path analysis exemplified that Part-time Job Willingness served as an endogenous mediating variable and was linked with Apprenticeship Willingness. Path analysis revealed that perceived independence and self-guidance evaluations varied significantly with part-time job willingness. Independence Interest showed the strongest, although negative, relationship with part-time job willingness. Initiative showing and part-time job were not linked in a statistically significant way. The relationship with Part-time Job Willingness and Apprenticeship Choice was positive and significant. Self-guidance want had a significant direct positive relationship with Apprenticeship. The aggregate impacts and unique situations of variables have to be taken into consideration when interpreting the path analysis model of this study. In aggregation, any single sample of behavior reflects not only the relevant general disposition, but also the influence of various other factors unique to the particular occasion, situation, and action being observed (see Ajzen 1991). It is also worth noting that path analysis reveals provide estimates of assumed causal effect that one variable has on another through its causal effect on other variables, but it does not prove causation between one variable and another, ort the direction of the assumed causal order.

The limitations of this study should also be noted. First, the sample represented students' intentions in one geographic region, and second, at the time of the study apprenticeship was a system widely considered as an entry point for adults. However, the Finnish school system presented a case of a homogeneous national curriculumbased educational system where interschool and interdistrict differences were relatively small. This can be argued to support the generalizability of the findings in this study. On the other hand, the latter limitation could have had impacts on guidance practices and thus weakened the respondents' knowledge of and beliefs about the concept. The sample of the study satisfied the technical assumptions of psychological person-based testing, and factor analytic and Path Analysis in SEM methodology (see Kline 2000; Loehlin 2009; Westland 2012). Part-time willingness was not considered intention as specified in the original TPB model, and neither was the Apprenticeship willingness behavior in the strict sense. Both constructs used in this study were argued to carry attributes of intention and behavior justifying their use in the adapted TPB model. In this study the variable of concern were placed in a stratified model adaptation. Considering the limitations, it can be seen that the adapted TPB model in this study needs further empirical evidence to further validate it and to increase its generalizability. 
Table 4 Intercorrelation Matrix of the Adapted TPB Path Model

\begin{tabular}{llllll}
\hline Variables & $\begin{array}{l}\text { Self- } \\
\text { guidance }\end{array}$ & $\begin{array}{l}\text { Independence } \\
\text { interest }\end{array}$ & $\begin{array}{l}\text { Initiative } \\
\text { showing }\end{array}$ & $\begin{array}{l}\text { Part-time } \\
\text { Job }\end{array}$ & Apprenticeship \\
\hline 1 Self-guidance & 1 & & & & \\
$\begin{array}{l}2 \text { Independence } \\
\text { interest }\end{array}$ & .39 & 1 & & & \\
3 Initiative showing & .30 & .50 & 1 & 1 & \\
4 Part-time Job & .07 & -.09 & -.00 & .19 & 1 \\
5 Apprenticeship & .15 & .04 & .04 & & \\
\hline
\end{tabular}

\section{Conclusion}

\section{Practical implications}

Students at the end of their nine-year elementary education have to make important decisions concerning their future education and choice of occupations. Career awareness is fundamental to career exploration, preparation and choice (Turner and Lapan 2013). Activities intended to prepare students to make and implement satisfying choices are part of the developmental aims of vocational guidance and career education services (Brown and Lent 2013). At about age 11, students enter a tentative age and become aware of themselves in relation to the world of work (Turner and Lapan 2013). Research supports the notion that school-to-work transition should be guided by the educational and career development needs of students (Hackett 2002).

Individuals interact with their environment and derive information from it. Workrelated attitudes, habits, and interpersonal skills serve as important predictors of job success and satisfaction (Fitzgerald 1986). Deci and Ryan (1985) have shown how choices initiate and regulate self-determined behaviors, and how a person chooses to behave in anticipation of achieving self-related goals and satisfying organismic needs. The findings of this study revealed a tentative behavioral predictive model and they contribute to understanding apprenticeship training and learning conation in vocational education and training (VET); thus, it is hoped that this paper will contribute to Ajzen's idea of "significance."

Self-guidance significantly converged to apprenticeship willingness in the path model. Attributes of self-determination and self-efficacy were present in apprenticeship orientation. This discovery may have implications for educational-vocational interventions that strive to individualize educational paths in VET and could encourage behavioral change. It underlines the importance of facilitating students' self- and occupational awareness and promoting their behavioral control of self-determination and selfefficacy during the transitional period before the entry into vocational secondary education or the world of work. The data gave tentative evidence of a link between SelfDirection and apprenticeship willingness that could partially explain student choice of apprenticeship. The study gave preliminary evidence to support a conclusion that initiative showing interest and self-guidance want supported conation for apprenticeship as a choice of further vocational training possibility. Latent factors of self-direction in learning covary with conation. Individual predictive behavioral models, designed and specifically selected for time, target, space, and location, are proposed to be used for both curriculum planning and person-based guidance counseling when supporting students during transitional periods from school to apprenticeships. 


\section{Competing interests}

The author declares that he has no competing interests.

Received: 28 January 2014 Accepted: 9 June 2014

Published online: 05 July 2014

\section{References}

Ainley P, Rainbird H (1999) Apprenticeship: Towards a new Paradigm of Learning. The Future of Education from 14+. Kogan Page Limited, London

Ajzen I (1985) From Intentions to Actions: A Theory of Planned Behavior. In: Kuhi J, Beckmann J (ed) Action-Control: From Cognition to Behavior. Springer, Heidelberg, pp 11-39

Ajzen I (1987) Attitudes, Traits and Actions: Dispositional Prediction of Behavior in Personality and Social Psychology. In: Berkowitz L (ed) Advances in Experimental Social Psychology 20. Academic, New York, pp 1-63

Ajzen I (1988) Attitudes, Personality and Behavior. Dorsey Press, Chicago

Ajzen I (1991) The theory of planned behavior. Organ Behav Hum Decis Process 50:179-211

Ajzen I (2002) Perceived behavioral control, self-efficacy, locus of control and the theory of planned behavior. J Appl Soc Psychol 4:665-683

Ajzen I (2005) Attitudes, Personality and Behavior. Open University Press, Berkshire

Ajzen I, Fishbein M (1977) Attitude-behavior relations: a theoretical analysis and review of empirical research. Psychol Bull 5:888-918

Ajzen I, Fishbein M (1980) Understanding Attitudes and Predicting Social Behavior. Prentice-Hall, Englewood Cliffs, NJ

Allmendinger J (1989) Educational systems and labour market outcomes. Eur Sociol Rev 5:231-250

Armitage CJ, Conner M (2001) Efficacy of the theory of planned behavior: a meta analytic review. Br J Soc Psychol 40:471-499

Babakus E, Ferguson CE, Jöreskog KG (1987) The sensitivity of confirmatory maximum likelihood factor analysis to violations of measurement scale and distributional assumptions. J Mark Res 37:72-141

Bandura A (1977) Self-efficacy: toward a unifying theory of behavioral change. Psychol Rev 84:191-215

Bandura A (1989) Human agency in social cognitive theory. Am Psychol 44:1175-1184

Bandura A (1997) Self-Efficacy: The Exercise of Control. Freeman, New York

Becker G (1975) Human Capital. NBER, New York

Bovaird JA, Koziol NA (2012) Measurement Models for Ordered-Categorical Indicators. In: Hoyle RH (ed) Handbook of Structural Equation Modeling. The Guilford Press, New York, pp 495-511

Breckler SJ, Greenwald AG (1986) Motivational Facets of the Self. In: Sorrentino RM, Higgins ET (ed) Handbook of Motivation and Cognition. Guilford Press, New York, pp 145-164

Brockett RG, Hiemstra R (1991) Self-Direction in Adult Learning: Perspectives on Theory, Research, and Practice. Routledge, London and New York

Brown SD, Lent RW (2013) Career Development and Counseling. Putting Theory and Research to Work. Wiley, Hoboken, New Jersey

Campbell DP, Hyne SA, Nilsen DC (1992) Manual for the Campbell Interest and Skill Survey. National Computer Systems, Minneapolis, MN

Clason DL, Dormody TJ (1994) Analyzing data measured by individual Likert-type items. J Agric Educ 35:31-35

Conner M, Armitage CJ (1998) Extending the theory of planned behavior: a review and avenues for further research. J Appl Psychol 15:1429-1464

Cronbach LJ (1946) Response sets and test validity. Educ Psychol Meas 6:475-494

Deci EL, Ryan RM (1985) Intrinsic Motivation and Self-Determination in Human Behavior. Plenum Press, New York and London

Deci EL, Ryan RM (1991) A Motivational Approach to Self: Integration in Personality. In: Dienstbier R (ed) Nebraska Symposium on Motivation. University of Nebraska Press, Lincoln, NE, pp 237-288

Dweck CS (2000) Self-Theories: Their Role in Motivation, Personality, and Development. Psychology Press Taylor and Francis. Group, New York

Epstein S (1990) Cognitive-Experiental Self-Theory. In: Pervin L (ed) Handbook of Personality: Theory and Research. Guilford, New York, pp 165-192

European Commission (2012) Assessment of key Competencies in Initial Education and Training. Commission Staff Working Document, Strasbourg

Fishbein M, Ajzen I (1975) Belief, Attitude, Intention and Behavior: An Introduction to Theory and Research. AddisonWesley, Massachusetts

Fitzgerald LF (1986) On the essential relations between education and work. J Vocat Behav 28:254-258

Gable R (1986) Instrument Development in the Affective Domain. Kluwer-Nijhoff, Hingham, MA

Garonna P, Ryan P (1991) The Regulation and Deregulation of Youth Economic Activity. In: Ryan P, Garonna P, Edwards R (ed) The Problem of Youth. Macmillan, London

Garson DG (2012a) Path Analysis. Blue Book Series. Statistical Publishing Associates, Asheboro

Garson DG (2012b) Structural Equation Modeling. Statistical Publishing Associates, Asheboro

Guglielmino LM, Guglielmino PJ (1988) Self-Directed Learning in Business and Industry: An Information age Imperative. In: HB Long \& Associates Self-Directed Learning: Application \& Theory. University of Georgia, Adult Education Department, Athens, Georgia, pp 125-148

Hackett G (2002) Self-Efficacy in Career Choice and Development. In: Bandura A (ed) Self-Efficacy in Chancing Societies. Cambridge University Press, Cambridge

Hancock GR, Liu M (2012) In: Hoyle RH (ed) Handbook of Structural Equation Modeling. New York, The Guilford Press Hannan D, Raffe D, Smyth E (1996) Cross-National Research on School to Work Transitions: An Analytic Framework, OECD, Paris. In: P Werquin, R Breen, J Planas (eds) Youth Transitions in Europe: Theories and Evidence. Documentes Séminaires No 120. CEREQ, Marseille 
Harrington J, Harrington T (1996) Ability Explorer: Preliminary Technical Manual. Chicago, IL, Riverside Hartung PJ (2013) The Life-Span, Life-Space Theory of Careers. In: Brown SD, Lent RW (ed) Career Development and Counseling. Putting theory and research to work. Second Edition. John Wiley and Sons Inc., New Jersey, pp 83-113 Holland JL (1997) Making Vocational Choices, 3rd edition. Psychological Assessment Resources, Odessa, FL

Holland J, Powell A, Fritzsche B (1994) The Self-Directed Search Professional user's Guide. Psychological Assessment Resources, Odessa, FL

Hoyle RH (ed) (1995) Structural Equation Modeling: Concepts, Issues and Applications. Sage Publications, Thousand Oaks, California

Hoyle RH (ed) (2012) Handbook of Structural Equation Modeling. The Guilford Press, New York

lannelli C, Raffe D (2007) Vocational upper-secondary education and the transition from school. Eur Sociol Rev 23:49-63

Kersh N, Evans K (2010) Facilitating learners' Motivation and Competence Development in the Workplace: The UK Context. In: Rauner F, Smith E (ed) Rediscovering Apprenticeship. Research Findings of the International Network on Innovative Apprenticeship (INAP. Springer, Dordrecht, Heidelberg, London, New York

Kidd JM (2006) Understanding Career Counseling. Theory, Research and Practice. SAGE publications Ltd, London Kline P (2000) Handbook of Psychological Testing, 2nd edition. Routledge, Milton Park, UK

Lent RW (2013) Understanding and Facilitating Career Development in the 21 st Century. In: Brown SD, Lent RW (ed) Career Development and Counseling. Putting theory and research to work. Second Edition. John Wiley and Sons Inc., New Jersey, pp 1-26

Lent RW, Brown SD, Hackett G (1994) Toward a unifying social cognitive theory of career and academic interest, choice, and performance. J Vocat Behav 45:79-122

Lerman RL (2010) Apprenticeship in the United States: Patterns of Governance and Recent Developments. In: Rauner F, Smith E (ed) Rediscovering Apprenticeship. Research Findings of the International Network on Innovative Apprenticeship (INAP. Springer, Dordrecht, Heidelberg, London, New York

Loehlin JC (2009) Latent Variable Models. An Introduction to Factor, Path, and Structural Equation Analysis. Taylor Francis e-Library, Lawrence Erlbaum Associates, Inc, New Jersey

Malone PS, Lubansky JB (2012) Preparing Data for Structural Equation Modeling: Doing Your Homework. In: Hoyle RH (ed) Handbook of Structural Equation Modeling. The Guilford Press, New York, pp 263-295

Marsden D (1986) The end of Economic man? Wheatsheaf, Brighton

Marsh HW, Balla JR, McDonald RP (1988) Goodness of fit indexes in confirmatory factor analysis. The effect of sample size. Psychol Bull 103:391-410

Marsh HW, Balla JR, Hau KT (1996) An Evaluation of Incremental fit Indexes: A Clarification of Mathematical and Empirical Properties. In: Marcoulides GA, Schumacker RE (ed) Advanced Structural Modeling Techniques. NJ pp, Lawrence Erlbaum, Mahwah, pp 315-353

Maurice M, Sellier F, Silvestre J (1986) The social foundations of industrial power: a comparison of France and Germany. MIT Press, Cambridge, MA

Miller A (1991) Personality types, learning styles and educational goals. Educ Psychol 11:217-238

Mitchell LK, Krumboltz JD (1990) Social Learning Approach to Career Decision Making: Krumboltz' Theory. In: Brown D, L Brooks and Associates (ed) Career Choice and Development, 2nd edition. Jossey-Bass, San Francisco, pp 145-196

Müller W, Shavit Y (1998) The Institutional Embeddedness of the Stratification Process. In: Shavit Y, Müller W (ed) From School to Work. Clarendon, Oxford

National Board of Education (2004) The comprehensive school core curriculum. Vammalan Kirjapaino, Vammala, Finland

Nauta MM (2013) Holland's Theory of Vocational Choice and Adjustment. In: Brown SD, Lent RW (ed) Career Development and Counseling. Putting theory and research to work. Second Edition. John Wiley and Sons Inc., New Jersey, pp 55-82

Olson JM, Zanna MP (1993) Attitudes and attitude change. Annu Rev Psychol 44:117-154

Oppenheim NA (1992) Questionnaire Design, Interviewing and Attitude Measurement, Newth edition. Continuum, New York, NY

Rauner F, Smith E (2010) Rediscovering Apprenticeship. Research Findings of the International Network on Innovative Apprenticeship (INAP). Springer, Dordrecht, Heidelberg, London, New York

Rosenbaum J, Kariya T, Settersten R, Maier T (1990) Market and network theories of the transition from high school to work: a cross-national perspective. Annu Rev Sociol 16:263-299

Rust J, Golombok S (1999) Modern Psychometrics. The Science of Psychological Assessment, 2nd edition. Routledge, New York

Schafer JL, Olsen MK (1998) Multiple imputation for multivariate missing-data problems: a data analyst's perspective. Multivariate Behavioral Research 33:545-571

Schumacker RE, Lomax RG (2004) A beginner's Guide to Structural Equation Modeling, 2nd edition. Lawrence Erlbaum Associates, Mahwah, NJ

Spence A (1974) Market Signaling. Harvard University Press, Boston

Super DE (1957) The Psychology of Careers. Harper and Row, New York

Super DE (1974) Measuring Vocational Maturity for Counseling and Evaluation. American Personnel and Guidance Association. Washington, DC

Super DE (1980) A life-space, life-span approach to career development. J Vocat Behav 16:282-298

Sutton S (1998) Predicting and explaining intentions and behavior: How well are we doing? J Appl Soc Psychol 15:1317-1338

Swanson JL, Schneider M (2013) Minnesota Theory of Work Adjustment. In: Brown SD, Lent RW (ed) Career Development and Counseling. Putting theory and research to work. Second Edition. John Wiley and Sons Inc., New Jersey, pp 29-53

Tapola A, Niemivirta M (2008) The role of achievement goal orientations in students' perceptions of and preferences for classroom environment. Br J Educ Psychol 78:291-312

Thurow L (1975) Generating Inequality. Macmillan, London 
Turner SL, Lapan RT (2013) Promotion of Career Awareness, Development, and School Success in Children and Adolescents. In: Brown SD, Lent RW (ed) Career Development and Counseling. Putting theory and research to work. Second Edition. John Wiley and Sons Inc., New Jersey, pp 539-564

West SG, Finch JF, Curran PJ (1995) Structural Equation Models With non-Normal Variables: Problems and Remedies. In: Hoyle RH (ed) Structural equation modeling: Concepts, Issues and Applications. Sage Publications, California Westland JC (2012) Modern Path Analysis \& Structural Equation Models. Kindle Book. www.amazon.com

Wolf A (2002) Does Education Matter? Myths About Education and Economic Growth. Penguin Press, London Zimmerman BJ (2000) Attaining Self-Regulation: A Social Cognitive Perspective. M Boekarts, PR Pintrich, Handbook of self-regulation, Academic Press, Harcourt Brace, San Diego, In, pp 13-39

doi:10.1186/s40461-014-0007-z

Cite this article as: Friberg: Apprenticeship orientation as planned behavior in educational choices: a path model

of antecedent beliefs. Empirical Research in Vocational Education and Training 2014 6:7.

\section{Submit your manuscript to a SpringerOpen ${ }^{\circ}$ journal and benefit from:}

- Convenient online submission

- Rigorous peer review

- Immediate publication on acceptance

- Open access: articles freely available online

- High visibility within the field

- Retaining the copyright to your article

Submit your next manuscript at $>$ springeropen.com 